\title{
Financing Sources of Exploration Works in the Light of Risk Related to their Activity
}

\author{
Arkadiusz KUSTRA ${ }^{1)}$, Barbara KOWAL ${ }^{2)}$, Robert RANOSZ ${ }^{3)}$
}

${ }^{1)}$ AGH University of Science and Technology, Cracow, Poland; email: kustra@agh.edu.pl; correspondence author
${ }^{2)}$ AGH University of Science and Technology, Cracow, Poland; email: bkowal @agh.edu.pl
${ }^{3)}$ AGH University of Science and Technology, Cracow, Poland; email: rranosz @agh.edu.pl

http://doi.org/10.29227/IM-2021-01-12

Submission date: 16-01-2021 | Review date: 22-05-2021

Abstract
The article presents an overview of the determinants of exploration works and the definition of the role of junior mines in those process-
es. Junior mines, as special purpose vehicles, focus on the stages of exploration and documenting of the deposits, without going into the
operational stage related to the exploitation. Due to their nature, those entities finance their activities with equity capital in the form
of share issues on the capital markets, addressing their proprietory securities to investors who accept a high level of risk. The largest
stock exchanges on which the exploration companies obtain the required funds have been identified, and the trends that complement
capital raising, concerning the involvement of private equity funds, have been presented.

Keywords: mining, exploration, junior mines, financing

\section{Introduction}

Mining industry constitutes one of the primary sectors of economic development, especially in developing regions such as Africa and South America, where it is export leverage supporting the needs of developed economies. Such economies, which are based on modern and innovative sectors, utilise the resources obtained and processed in the complex production processes in the electronics and automotive industries. Japan is one of the examples, as even though it does not have mineral resources of its own, it is still the world's biggest consumer of mineral resources, importing them from various parts of the world. Similar trends are also present in France [1]. Among developed countries, Australia is a unique phenomenon. Although the country is among the world's nine richest economies, it is the mining industry that its economic prosperity and the gross domestic product growth are based on.

The demand for raw materials has been increasing since the beginning of the twentieth century and based on the forecasts for 2050, it is unlikely to decrease [11]. Given the historical consumption trends, one should assume that the extraction of natural resources will actually increase. According to Global Resources Outlook, today's consumption trends indicate that the extraction of such resources as metal ores will be increasing by about $1.7 \%$ annually until 2060 [2]. This demand can only be met by increasing the production output of the already existing mines [7]. However, it is possible that with the current technological developments, the constant demand for mineral resources could also be met through the exploitation of the so-called anthropogenic deposits, including mining waste storage sites [3], as well as small deposits [4]. Although recycling methods are also being refined to help meet the demand for metals, they only supply a limited amount of them [4].

Therefore, obtaining and making new deposits of raw materials available to support the needs of modern and innovative economic processes is becoming a necessity if the fur- ther development of advanced technologies is to take place. This goal is achieved through explorations as well as through mergers and takeovers of deposits that have already been documented, which are effective alternatives to launching new geological-mining projects and providing the necessary raw materials.

Looking at the entire life cycle of the geological and mining projects, it should be remembered that it often takes many years from a discovery of a deposit to mass production [8], therefore the risk associated with them is usually multifaceted. The specificity of the works seems to justify the need for an individual approach to the problem of a proper selection of funding sources [12] and matching them to a specific stage of advancement in the whole life cycle. When analyzing the risk related to such a project, it should be noted that the risk varies and decreases with the progress of work. Undoubtedly, when analyzing the life cycle of a geological-mining project, the greatest risk of failure, and thus of incurring outlays which will not bring the intended economic effects, are the processes related to the exploration of the deposit and its estimation. The characteristics of such works in conjunction with their capital intensity is an interesting topic related to the selection of funding sources as well as the economic efficiency of the activities carried out in the context of the whole geological-mining project.

The market analyses confirm that there is currently a strict specialization that consists in shifting exploration works from large mining companies to junior mines, i.e. special purpose vehicles involved in such activities.

In the context of the above-mentioned issues, this article aims to present the funding sources of exploration works in the light of their specificity and conditions, which at the same time justify and legitimize the functioning of the special purpose vehicles, i.e. junior mines. Such entities are often listed on alternative capital markets where they try to raise funds for their activities 


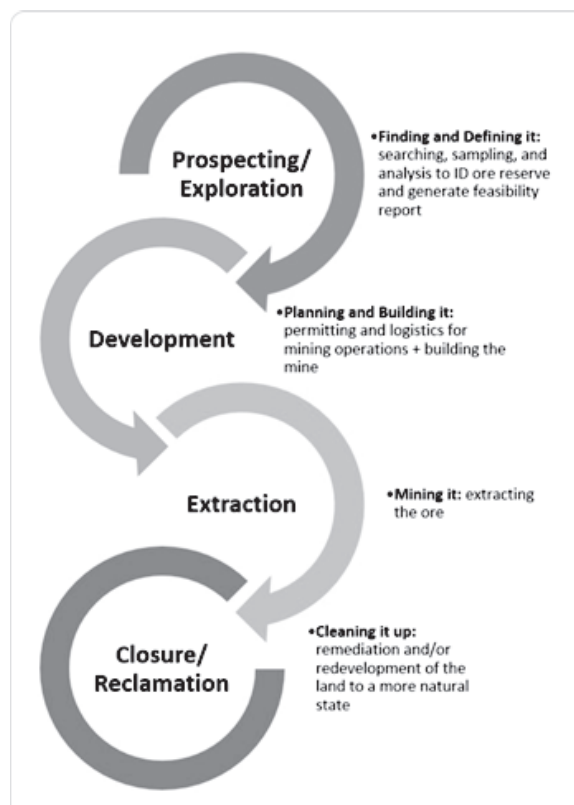

Fig. 1. Mine life cycle stages [22]

Rys. 1. Fazy cyklu życia projektu geologiczno-górniczego

\section{Materials and Methods}

For the purposes of this publication, a literature review was carried out to present the role of junior mines companies in the processes of carrying out exploration works. The publications were searched for using several search engines such as: Science Direct (Elsevier), Scopus or Gate Research. Each of them gave different search results. Terms such as "junior mines", "life cycle", "financing" and "stock exchange" were used to search for "title", "keyword" and "summary" of the indexed literature field. Initial searches and research in search engines resulted in a total of 136 publications that were of interest to the authors of this publication.

In the next step, a selection of publications was made, rejecting those that were not relevant to our questions and research considerations regarding the role of junior mines companies and sources of financing for exploration works. As a result, the focus was on 35 publications (including 16 articles and 16 reports) constituting the final dataset. On their basis, the characteristics of special purpose vehicles of the juniors mines type, exploratory works being part of the geological and mining project life cycle and financing of these works, taking into account the mine development phases, were made. Most of them were published between 2019-2020. A large part of them, in terms of geography, is related to Canada (TSV-X), Great Britain (AIM) and Australia (ASX), because there are the largest stock exchanges on which juniors are listed. These countries attracted mining companies to their financial market, providing opportunities for them to accumulate capital and develop them in the field of mining and related industries.

\section{Results}

In this section, the main results are described starting with the characteristic of effects in exploration work. Subsequently, it was presented the main type of enterprises, which are identified as junior mines. They carry out the explorations works, becoming the specialist ones in these processes.

\subsection{The characteristics of effects in exploration works}

Extraction works are part of a geological-mining project life cycle and constitute its vital element, as they determine its subsequent stages. The project life cycle is defined within the time horizon determined by the beginning and the end of a project.

A geological-mining project can be defined as activities carried out in the mining industry such as searching, sharing, extraction, dressing of the minerals and selling the enriched product [23]. The implementation of such a project is related to a mineral deposit, the extraction of which is the object of the operating activity of a mining company. Mineral deposits are very characteristic, which is evidenced by the rarity and the uniqueness of their occurrence both in terms of geological conditions as well as their location, non-renewability and uncertainty about the construction of resources and geological characteristics. Therefore, implementation of the geological-mining project is not only related to finding a deposit but also to obtaining licenses and permits to extract them. Implementation of such a project differs from the implementation of any other project in technical, technological and financial terms. The particularly distinctive features include [24]:

- long pre-production period which consists of searching for deposit and its evaluation, sharing and preparing for mining,

- long mining period,

- complex geological-mining conditions,

- high capital intensity,

- $\quad$ high cost of capital financing the project (long payback periods),

- production inflexibility,

- high operational risk (high fixed operating costs),

- $\quad$ price unexpectedness on natural resources market.

Therefore, the implementation of the discussed geological-mining works consists of several stages: exploration and recognition of mineral deposits, evaluation of a deposit, 


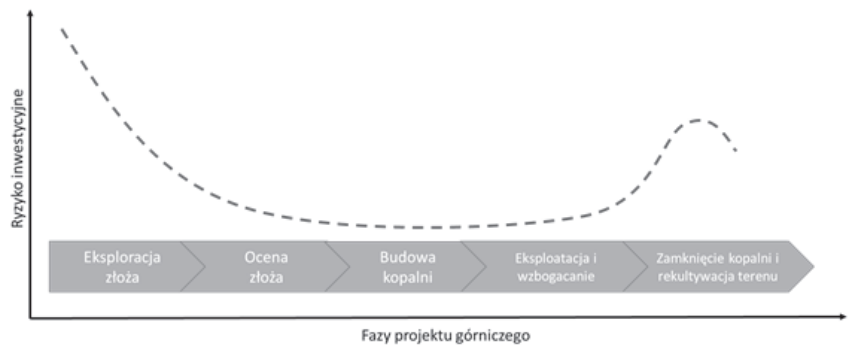

Fig. 2. The relationship between the investment risk and the stage of a mining and geological project's life cycle. Source: own study Rys. 2. Zależność pomiędzy ryzykiem inwestycyjnym a fazą cyklu życia projektu geologiczno- górniczego
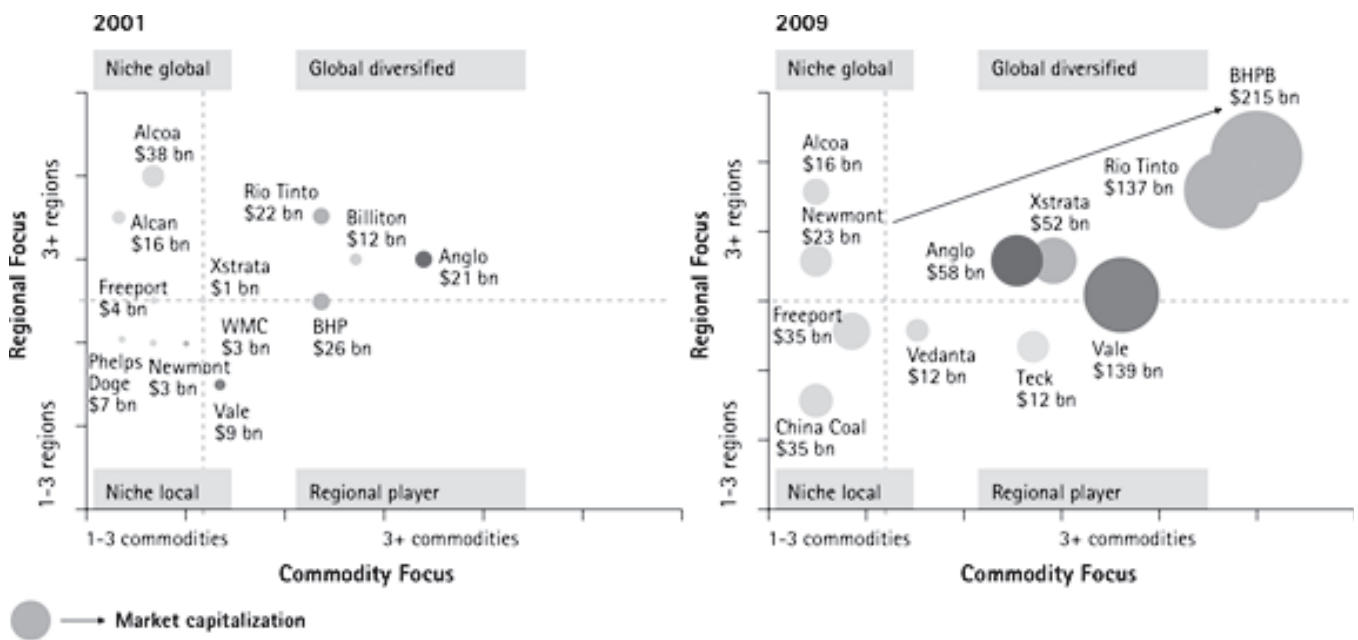

Fig. 3. Changes on the global mining market at the beginning of the 21st century [35] Rys. 3. Zmiany na światowym rynku górniczym od początku XXI wieku

building a mine, land exploitation and enrichment as well as liquidation and reclamation [25].

As a part of the exploration stage, the deposit is exposed and the mineral deposit is documented. The next stage, the assessment of the deposit, is reached by approx. $5 \%$ of the projects implemented in the exploration stage [26]. The analyses carried out in this stage are aimed at identifying the parameters that characterize the deposit. The works focus on determining whether the extraction of mineral resources is technically feasible and commercially reasonable (feasibility study). This stage ends with a decision to build the mine. This is the most capital-intensive stage, which requires the investor to obtain several permits, which may result in extending the stage in time. It requires identification of complete assets that would be fit for use and would ensure the exploitation at the level of the designed extraction capacities. After the mine is constructed and the preparation of the deposit for exploitation is completed, the mining production begins. The production process produces a mineral raw material with appropriate characteristics of a commercial product, which it obtained in the process of enrichment. This is a long-term stage. The last stage is a closure of the mine and reclamation of the area where the exploitation was conducted.

Given the above, it is noted that the life cycle of the geological-mining project is identified directly with the life cycle of the mine (Fig. 1). A mine's life cycle includes the following stages [22]:

- prospecting and exploration,

- development,
- extraction,

- closure/reclamation.

It is worth noting, that it may be difficult to distinguish the individual stages of economic activity as some processes may overlap or occur in parallel during certain periods.

Exploration works consist in finding and documenting mineral deposits; in particular, they include:

- analysis of historical geological data,

- topographical analyses,

- geological analyses,

- geochemical and geophysical analyses,

- $\quad$ exploratory drilling,

- sampling.

Such exploration works can only be performed after the relevant rights and licenses have been obtained.

Since as much as $95 \%$ of projects never go past the exploration stage and reach the deposit evaluation stage, exploration and identification of deposits bears the highest risk of failure. The relationship between the investment risk and the stage of a mining and geological project's life cycle is presented in Figure 2.

When analyzing the entire life cycle of a project, it is evident that the risk changes depending on the stage of its implementation (fig. 2). The initial stage, being mostly exploration, is characterized by a high risk of failure, demanding at the same time high investment assets, related to the necessity of relevant research and analyses. Investment outlays typical- 


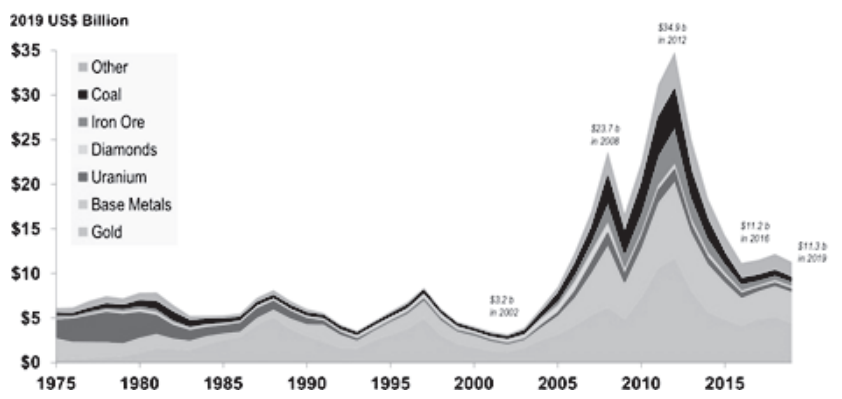

Fig. 4 Exploration expenditures on particular types of raw materials between 1975-2018 [36]

Rys. 4. Wydatki eksploracyjne w zależności od rodzaju surowców w latach 1975-2018

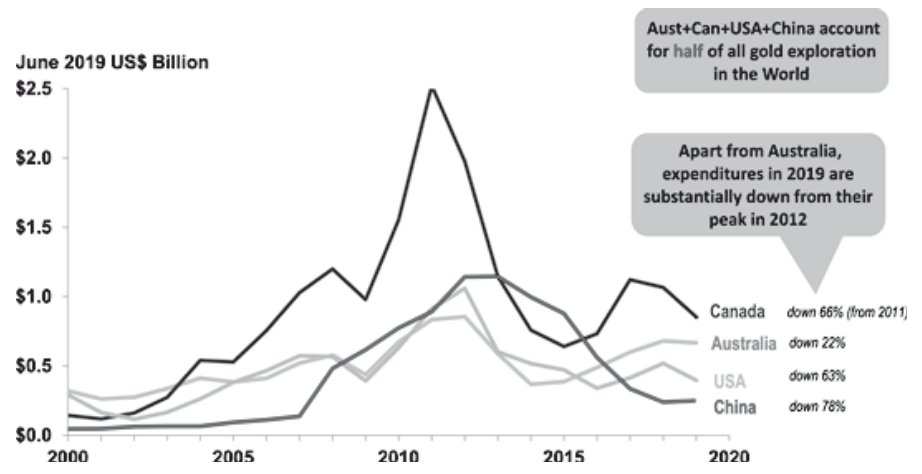

Fig. 5. Changes in exploration expenditures in the four countries that represent the largest market for exploration [36] Rys. 5. Zmiany w wydatkach na eksplorację na przykładzie czterech krajów reprezentujących największe rynki eksploracyjne

ly amount to about a few percent of the value of the whole project (approx. 10-15\%). The highest level of risk out of all project stages is due to the exploration works undertaken during this stage, including the drilling of exploratory wells, which does not always result in a deposit being discovered. In practice, one can never be certain that such works will lead to the discovery of commercial deposits. As the works on the exploration and the development of the deposit progress, the business risk decreases, although, in fact, it accompanies the investor until the end of the operation of the project.

Then, for projects that go further to the assessment stage of the deposit, the risk decreases significantly. The lowest risk occurs at the stage of the mine construction, the exploitation and the enrichment, i.e. once all parameters are known, the knowledge of the mineral is high enough and appropriate research and analysis have been carried out. Potential investors and capital providers pay attention to financial aspects, but above all, to technical or technological data concerning geological and mining information, the most of which occur, as mentioned, at the exploration stage. The decisions to start the investments in exploration, development and subsequent extraction of minerals from the deposit require a large initial capital commitment, while the economic benefits of the project are usually generated after a few or more years from the discovery of the deposit. Therefore, it is the characteristics of the deposit (the rarity of occurrence, the natural limitation, the lack of a possibility of estimating them unequivocally) that determine the financial success of the investor. The size of the deposit and resources is the basic condition for investment activity in mining. And the geological conditions of the occurrence of the mineral (the form of the deposit, the size of resources and the quality of the mineral) and the possibilities of its extraction determine the profitability of this investment. The deposits located close to the surface, with large resources and large thickness, are more economical than the small ones with a complicated structure, located much deeper.

\subsection{Junior mines as a special purpose vehicle dealing with exploration works}

Global consolidation of the mining industry (a global process of taking over and merging) which occurred after the first decade of the 21 st century created more concentrated and limited mining market. Big companies using horizontal diversification model with diversified production and geographical location, identified with individual business segments within a specific business model started to dominate the market. (Figure 3)

The changes made most often through processes of merging and taking over led to shaping the specific market structure of mining companies in which one can distinguish three types of mining companies:

- senior mines,

- medium mines,

- junior mines.

The classification border between the classes of individual companies is blurred and the criteria for the division are different. For example, M. Dougherty uses the size of its assets as a classification criterion, i.e. senior mines would be mining companies with assets exceeding $\$ 3$ billion, medium mines 


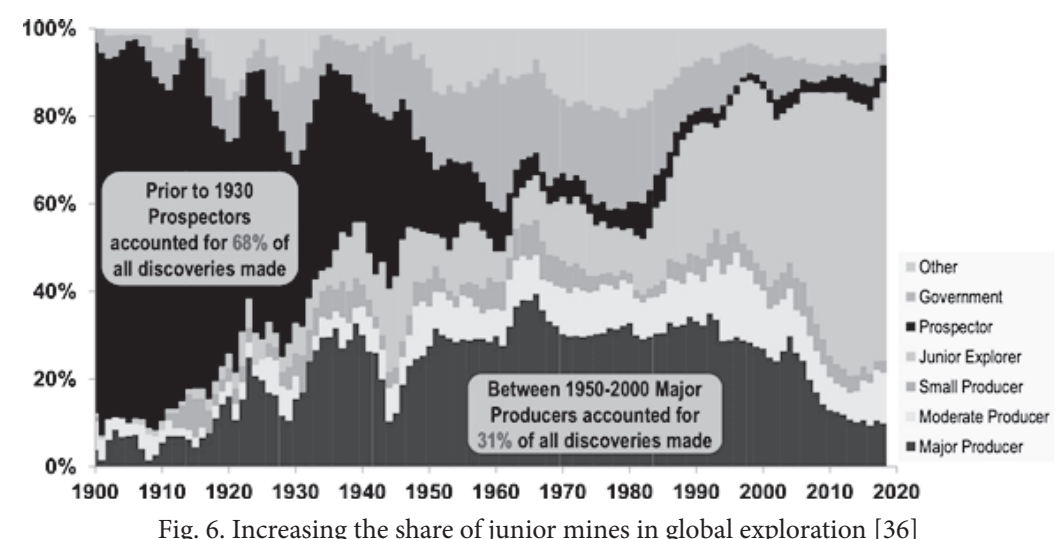

Fig. 6. Increasing the share of junior mines in global exploration [36] Rys. 6. Wzrost udziału junior mines w eksploracji na świecie

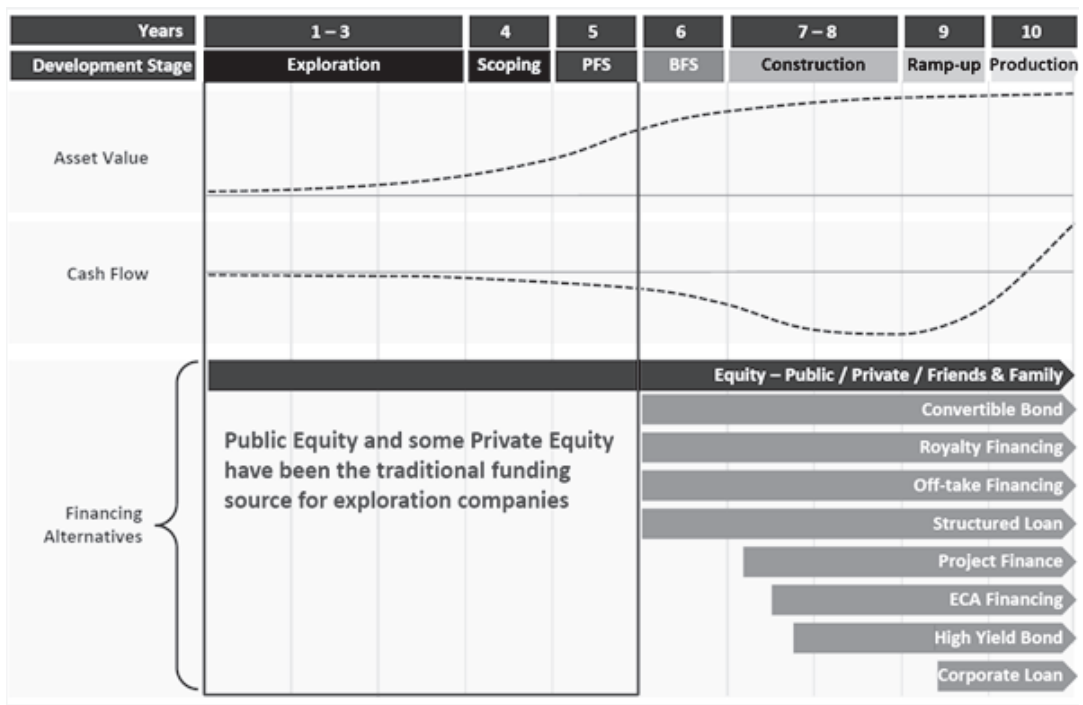

Fig. 7. Mine development stages and traditional sources of funding [32]

Rys. 7. Fazy rozwoju projektu geologiczno- górniczego a tradycyjne źródła finansowania

between $\$ 1$ billion and $\$ 3$ billion, and junior mines below $\$ 1$ billion [28]. D. Cranstoun, on the other hand, distributes the classes by a source of income assuming that: seniors would generate revenues mainly from the extraction and sale of minerals, juniors would depend primarily on effective processes of exploration and sale of documented deposits without production, and the mediums would generate revenues in a complementary manner from both sources [18].

In the light of the cited classifications, it can be concluded that the structure of the mining market has been determined by the revenue generated but also by the specialization of works within the life cycle of deposits identified as geological-mining projects.

The increase in exploration expenditures over the years has become a necessity for extending the life of mining operations but also for increasing of future mining. (Figure 4) The figure shows that the successive increase in exploration expenditures had its highest value in 2012, and the value of exploration expenditures was approximately $\$ 34.9$ billion. As for the type of raw materials that absorbed the highest capitals at the exploration stage, it must be admitted that gold is invariably the leader. Base metals such as copper, zinc, lead or aluminium also have a significant share. In the last two years, i.e. 2018-2020, according to the $\mathrm{PwC}$ report, we can observe a transfer of high exploratory intensity to lithium and cobalt, which are necessary for new technologies very often related to the broadly understood electromobility.

As far as the countries with the largest exploration expenditures are concerned, they can actually be considered to be the largest in countries where regulations encourage this type of activity and at the same time where exploration companies can count on raising capital for such activity. Figure 5 displays the domination of four countries - Canada, Australia, USA and China.

Most of the investment expenditures made in the exploration works were made by junior mines companies. Figure 6 shows the share of exploration companies in the total global exploration effort; this share has been systematically increasing since the 1980s. In the last decade, more than $65 \%$ of all discoveries of new deposits were made by junior mines.

The rapid growth of junior mines was caused by specialization and the desire to separate the risks of existing mining businesses from exploration. The transfer of risk to special purpose companies has become effective for the largest mining concerns. Due to their specificity, junior mines companies need to finance their significant investment expenditures, which is why they participate in the capital market, where they try to obtain the necessary funds by issuing shares, most often 


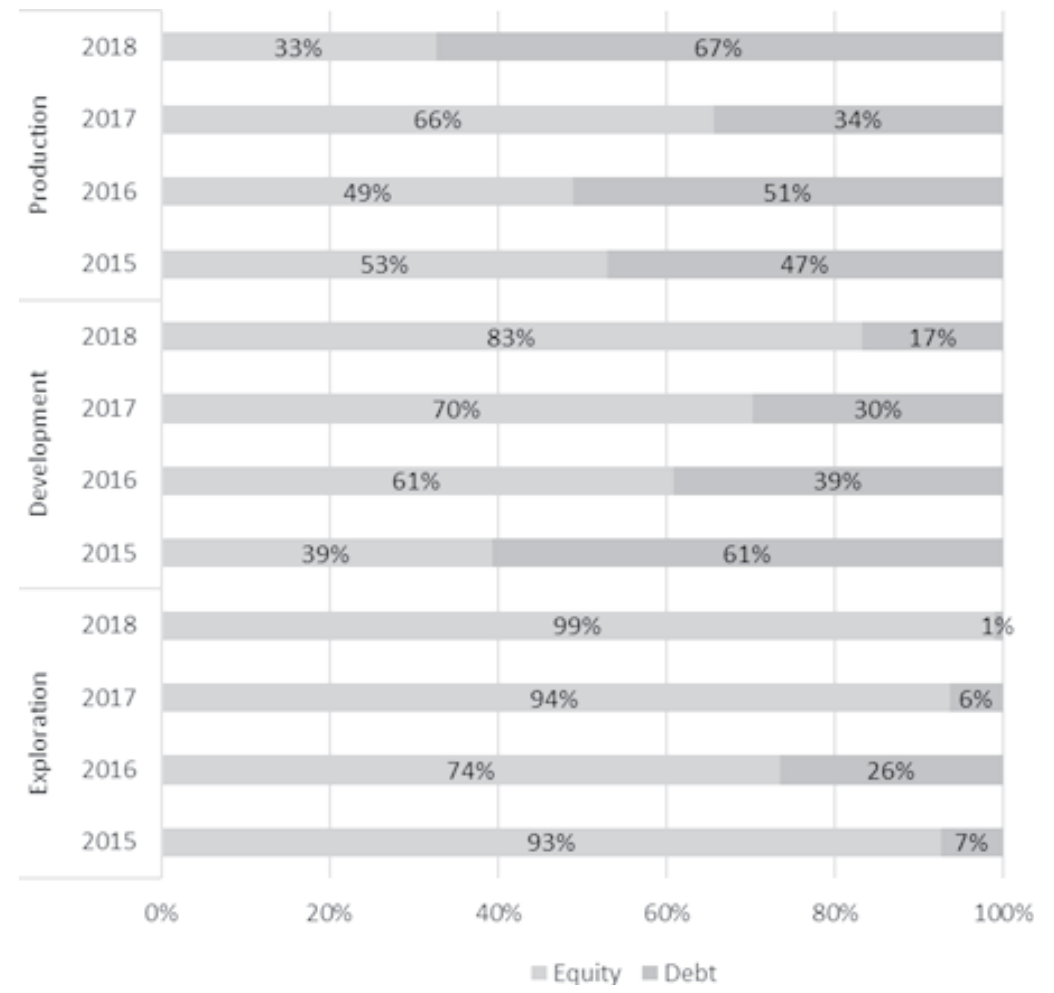

Fig. 8. Level of financing of juniors mines with equity and foreign capital in 2015-2018 [20] Rys. 8. Poziom finansowania spółek typu juniors przy wykorzystaniu kapitału własnego i długu

in alternative markets. The largest and most effective markets for such companies are found on the London, Toronto and Sydney stock exchanges. At the same time, the valuations of junior mines on the stock exchanges are generally low for the mineral sector, and their appreciation is conditioned by information about the mineral potential of the sought-after areas and the progress of projects" [30]. The implementation of projects by these companies or, more precisely, the possibility of finding economically viable extraction resources is significantly limited. Therefore, investments in these companies are subject to high risk. The risk also results from possible manipulation of information disclosed by mining companies [31]

\section{Discussion}

In the light of the presented models for the realization of exploration works, this chapter presents the types of funding and trends in the financing of exploration works carried out by junior mines.

Exploration works as the first stages in the implementation of projects generate expenses and potential revenues (or possibly profits) appear only in the operational stage related to the operation of the project. A drawing showing the generated assets, cash flow and financing sources at each stage of the life cycle is presented below.

As Figure 7 shows, the sources of funding in the exploration stage basically focus on equity only, which can come from the owners' contributions as well as form the issuance of shares on the capital markets. It is only at the stage of both technical and economic feasibility studies that it is possible to raise foreign capital and debt financing. The consequence of the presented trends and their conclusions is that junior mines dealing with exploration works have to raise equity for their activities, looking for opportunities to enter capital mar- kets and distribute shares to potential owners. The funding structure for the individual life cycle phases of mining companies (Figure 8) in the years 2015 to 2018.

Figure 8 confirms the share of foreign capital in the financing of geological-mining projects with an increase in their advancement and a simultaneous reduction of investment risk. foreign capital financing at individual stages of the life cycle. In the case of juniors companies, which are mainly interested in the first stage (exploration), equity financing exceeds $90 \%$ (except for 2016, when equity financing was at the level of approximately $74 \%$ ).

Within the framework of stock exchanges, these companies may issue shares on the capital markets, and in particular on the so-called alternative markets. [30]. The choice of such markets for juniors companies is due to the fact that they do not meet the requirements to enter the main market.

The biggest quotation markets for juniors companies in the mineral sector are:

- Toronto Stock Exchange (TSX) in Canada, the TSXV alternative market.

- Australian Securities Exchange (ASX) in Australia,

- London Stock Exchange (LSE) in England, AIM alternative exchange

The location of stock exchanges in these countries is primarily due to the predictable and stable regulatory environment and the proximity of some areas rich in minerals, i.e.: the proximity of London to Africa, Canada to all the Americas and Australia to Asia, Africa and Australia. These countries have attracted mining companies to their financial market by providing opportunities to raise capital and develop them in mining and related industries. 


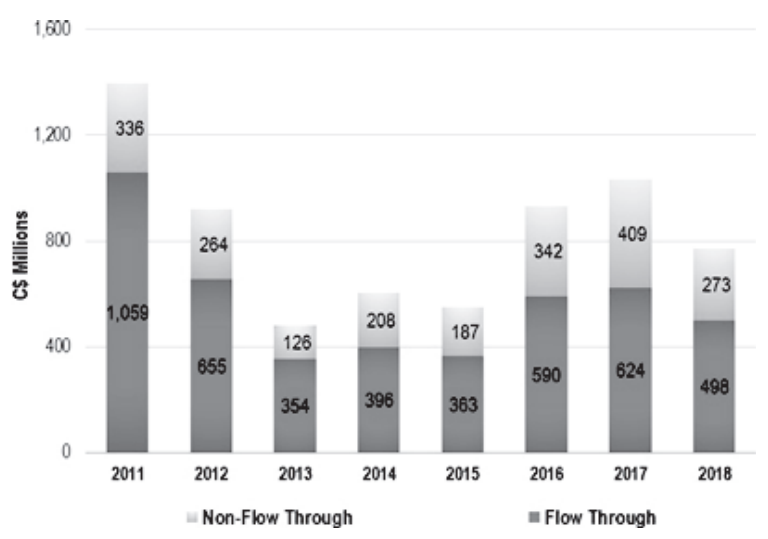

Fig. 9. Canadian exploration financing (2011-2018) [33]

Rys. 9. Finansowanie prac eksploracyjnych w Kanadzie

According to J. Bhandari, Canada has the highest number of junior mines listed on the stock exchange [13]. Thus, the Toronto Stock Exchange Venture (TSXV), as an alternative market, are leaders in raising finances for exploration companies. Many of the companies listed on these stock exchanges do not come from Canada, but they take advantage of the favourable regulatory and market conditions offered by Canada to obtain financing. It is about the stability of not only legal regulations but also investment incentives, created by the state to purchase shares of junior mines companies by potential shareholders. This includes several editions of the "Flow through shares" program (Figure 9)

In turn, by analyzing the Australian market in the context of exploration and potential incentives created by the state, it is also possible to identify programs of which two were the most significant:

- Plan for Accelerating Exploration (PACE) for the South Australia region, under which over 40 million US dollars were spent in 2004-2015;

- Exploration Incentives Scheme (EIS) supporting the Western Australia region, within which approximately 100 million US dollars have been spent between 2009-2017.

In each of them, there has been an intensification of searching and strengthening of the sector of Australian junior mines operating on the market.

In recent years, specialized private equity funds have also been very expansive in funding exploration works, complementing traditional sources of capital from the capital market. These funds are an alternative form of financing and are targeted at investments in the early stages of geological-mining projects. The most active ones include Orion Mine Finance, Resource Capital Funds, Taurus or Greenstone Resources.

Private equity offers funding to junior mines in exchange for minority shares in projects. They are also given influence on management and operational decisions to increase their profitability in the context of final sales.

The funds have also recently recognized opportunities to lengthen the value chain when financing projects and have combined investing in the exploration of new deposits with opportunities to secure priority in debt financing at subsequent stages of geological-mining activities; e.g. Orion obtained rights for debt financing for the Curraghinalt project, just like Greenstone Resources in the case of two copper projects, Coro and Excelsior [34].

Creating opportunities to earn money by offering different types of financial products for private equity funds at different stages of projects seems to be beneficial for the mining market and offers an opportunity to attract similar types of financing on a wider scale

\section{Conclusions}

Currently, mining companies operating on the market have to face challenges related to the general downturn, decrease in raw material prices, maintaining cost efficiency, and finally the need to implement new and innovative solutions to improve their geological and mining processes.

In the early stages of geological-mining activities, the identified exploration processes require financial expenditures, while incurring a very high investment risk, associated with the failure of exploration. In the light of the conditions and risk management, which determines the cost of raising the necessary capital, the exploration works are mostly carried out by junior mines special purpose companies. They usually raise equity through share issues on alternative markets, the largest of which operate in Toronto TSXV, London AIM and Sydney ASX. However, equity does not fill the existing financing gap at the earliest. Recently there has also been an observable activity of equity private funds, which offer funding to exploration companies. Having minority shareholding, they gain influence on the implementation of geological-mining projects, bringing them to the stage where a project with documented deposit can be resold. Nevertheless, some of the funds have seen opportunities of extension of licenses to earn money by ensuring the provision of capital at further stages of project development. Such an extension of the value chain for financial products owned by private equity funds is economically justified, but on the other hand, it should also have a positive impact on the development of the mining market. 


\section{Literatura - References}

1. Muller S., Lai F., Beylot A., Boitier B., Villeneuve J.: No mining activities, no environmental impacts? Assessing the carbon footprint of metal requirements induced by the consumption of a country with almost no mines, Sustainable Production and Consumption Volume 22April 2020, Pages 24-33

2. Global resources outlook 2019: Natural resources for the future we want, United Nations Environment Programme ; International Resource Panel, 2019.

3. Päivi H., Kinnunen M., Kaksonen A., H.:, Towards circular economy in mining: Opportunities and bottlenecks for tailings valorization Journal of Cleaner Production Volume 22810 August 2019 Pages 153-160

4. Moore K. R., Whyte N., Roberts D., Allwood J., Bloodworth A. J.: The redirection of small deposit mining: Technological solutions for raw materials supply security in a whole systems context Resources, Conservation \& Recycling: X Volume 7 September 2020 Article 100040

5. Oberle, B., Bringezu, S., Hatfield-Dodds, S., Hellweg, S., Schandl, H., Clement, J., Cabernard, L., Che, N., Chen, D., Droz-Georget, H., Ekins, P., Fischer-Kowalski, M., Flörke, M., Frank, S., Froemelt, A., Geschke, A., Haupt, M., Havlik, P., Hüfner, R., Lenzen, M., Lieber, M., Liu, B., Lu, Y., Lutter, S., Mehr, J., Miatto, A., Newth, D., Oberschelp, C., Obersteiner, M., Pfster, S., Piccoli, E., Schaldach, R., Schüngel, J., Sonderegger, T., Sudheshwar, A., Tanikawa, H., van der Voet, E., Walker, C., West, J., Wang, Z., Zhu, B., 2019. Global Resources Outlook 2019: natural Resources for the Future we Want

6. Steinbach, V., Wellmer F.W.: Consumption and use of non-renewable mineral and energy raw materials from an economic geology point of view. Sustainability 2, 2010, 1408 - 1430. https://doi.org/10.3390/su2051408

7. Humphreys, D.: Long-run availability of mineral commodities. Miner. Econ. 26, 2013, 1-11. https://doi. org/10.1007/s13563-013-0033-5

8. Rademeyer M.C., Minnitt R.C.A., Falcon, R.M.S.: A characterization of the mechanisms transforming capital investment into productive capacity in mining projects with long lead-times. Miner. Econ. https://doi.org/10.1007/ s13563-019-00213-3

9. Renner S., Wellmer F.W.: Volatility drivers on the metal market and exposure of producing countries. Miner. Econ. 2019, https://doi.org/10.1007/s13563-019-00200-8

10. Tiantian Zhang, Cherry Yi Zhang, Qifan Pei: Misconception of providing supply chain finance: Its stabilizing role International Journal of Production Economics Volume 213 July 2019 Pages 175-184

11. Christmann P.: Towards a more equitable use of mineral resources. Natural Resources Research 27, 2018,159-177. https://doi.org/10.1007/s11053-017-9343-6.

12. Dziworska K, Nowakowska L., Narzędzia oceny opłacalności górniczych projektów inwestycyjnych - doświadczenia i propozycje, Prace i Materiały Wydziału Zarządzania Uniwersytetu Gdańskiego, ISSN 1732-1565, rok 2012, Tom 10, Nr 4 cz. 3, str 267 - 281 [in Polish]

13. Jayant Bhandari, High Risk, High Reward: Disciplined Junior Mining Investing, The Guide published by Liberty.me, https://iberty.me/wp- content/uploads/2015/07/Bhandari-HighRiskHighReward-v10.pdf [access: 18.08.2020]

14. Junior Mine 2016, PwC, https://www.pwc.com/ca/en/industries/mining/publications/junior-mine-2016.html [access: 18.08 .2020$]$

15. Junior Mine 2017, PwC, https://www.pwc.com/ca/en/industries/mining/publications/junior-mine-2017.html, [access: 18.08.2020]

16. Junior Mine 2018, PwC, https://www.pwc.com/ca/en/industries/mining/canadian- mine/junior-mine-2018.html, [access: 18.08.2020]

17. Canadian Mine 2020, Report: Another successful year, https://resourceworld.com/pwc-canadian-mine-2020-report-another-successful- year/, [access: 18.08.2020]

18. Cranstoun D.: Effects of equity financing on valuation of junior gold mining companies in recessionary and post-recessionary economic realities of 2008-2010. The Leonard N. Stern School of Business, Glucksman Institute for Research in Securities Markets. New York. 2010.

19. Westland J.: Project Management Life Cycle, Kogan Page Limited, London, 2007, p.4 Copper Mining and Processing: Life Cycle of a Mine, https://www.superfund.arizona.edu/learning-modules/tribal-modules/copper/minelife-cycle

20. Uberman R., Wpływ rekultywacji gruntu na wartość złoża (przedsiębiorstwa górniczego). Gospodarka Surowcami Mineralnymi, tom 22, zeszyt specjalny 2, Wyd. IGSMiE PAN, Kraków 2006

21. A. Lisowski, Podstawy ekonomicznej efektywności podziemnej eksploatacji złóż, Wyd. GiG, PWN, Katowice-Warszawa 2001, p. 49 
22. Financial Reporting in the Mining Industry for the 21st Century, annual report Price WaterhouseCoopers, 2000

23. Wirth H., Cykl życia projektów górniczo-geologicznych i metody jego wyceny, Gospodarka Surowcami Mineralnymi, tom 22, zeszyt specjalny 2, Wyd. IGSMiE PAN, Kraków 2006

24. Dougherty M. L.: The global gold mining industry, junior firms and civil society resistance in Guatemala. Bulletin of Latin American, Research, v. 30, n. 4, p. 403-418, 2011.

25. Dougherty M. L.: The global gold mining industry: materiality, rent-seeking, junior firms and Canadian corporate citizenship. Competition \& Change, v. 17, n. 4, p. 339-354, 2013. ISSN 1024-5294.

26. Everett R., Gilboy A.: Impact of the World Bank Group's social and environmental Policies on extractive companies and financial institutions. Associates for Global Change. Washington 2003.

27. Milanez B., Mansur M., Wanderley J., Financeirização e o mercado de commodities: uma avaliação a partir do setor mineral, July 2019 Revista Tamoios 15(1), DOI: 10.12957/tamoios.2019.38676

28. Naylor R.T.: The alchemy of fraud: Investment scams in the precious-metals mining business. Crime Law Social Change, v. 47, p. 89-120, 2007.

29. Garlaban Consult LTD, Private Equity \& African Junior Mining Sector, ELG Workshop Warsaw September 2017

30. https://www.sedar.com/

31. Deneault A., Sacher W.: Imperial Canada Inc. - Legal haven of choice for the World's mining industries. Vancouver: Talon books, 2012.

32. Dougherty M. L.: Scarcity and control: The new extraction and Canada's mineral resource protection network. In: Denodian K., Dougherty M. L.: Mining in Latin America: Critical approaches to the new extraction. London; New York: Routledge, 2016.

33. https://www.pdac.ca/priorities/access-to-capital/flow-through-shares [access: 14.08.2020]

34. Preston G.: Private-Equity-Owning-Mines-A-New-Investment-Approach.

35. (https://www.kitco.com/commentaries/2018-07-03/Private-Equity-Owning-Mines-A-New-Investment-Approach. html [access: 24.08.2020])

36. Mining Executive Series, Global Operating Models for Mining Companies, Adding value beyond the individual assets, Accenture - report, 2015

37. Schodde R.: Trends in Exploration, presentation International Mining and Resource Conference, 30 th Octobe4 2019, Melbourne

Źródła finansowania prac eksploracyjnych $w$ świetle ryzyka zwiazanego z ich realizacja

$W$ artykule przedstawiono przegląd uwarunkowań prac poszukiwawczych oraz określenie roli spółek typu junior mines w tych procesach. Junior mines, jako spółki celowe, koncentruja się na etapach poszukiwania i dokumentowania złóż, nie wchodząc w fazę operacyjna związana z eksploatacją. Ze względu na swój charakter, podmioty te finansuja swoją działalność kapitałem własnym $w$ formie emisji akcji na rynkach kapitałowych, kierując swoje papiery wartościowe do inwestorów akceptujących wysoki poziom ryzyka. Zidentyfikowano największe giełdy, na których spółki eksploracyjne pozyskuja żródła finansowania oraz przedstawiono aktualne tendencje pozyskiwania kapitału, dotyczace zaangażowania funduszy private equity.

Słowa kluczowe: górnictwo, eksploracja, spółki junior mines, finansowanie 